\title{
Prevalence of diarrhoea and associated risk factors among children under five years old in Pader District, northern Uganda
}

\author{
Stephen Omona', Geoffrey M. Malinga ${ }^{1,2}$, Robert Opoke ${ }^{1,3}$, Geoffrey Openy ${ }^{4}$ and Robert Opiro ${ }^{1 *}$ (D)
}

\begin{abstract}
Background: Diarrhoea remains a major cause of morbidity and mortality in children under 5 years in sub-Saharan Africa. Of the three East African countries, Uganda has the worst mortality rate in children $<5$ years, with $22 \%$ of these deaths attributed to diarrhoea. For proper planning and implementation of control, an understanding of the prevalence and determinants of the disease is crucial. This study assessed the prevalence of diarrhoea and related risk factors among children < 5 years in Pajule Subcounty, Pader District in northern Uganda.

Methods: A cross-sectional survey was conducted in April 2018, covering 244 randomly selected households having children $<5$ years old in the study area. A semi-structured questionnaire was used to interview the households about diarrhoeal history in their children in the last 2 weeks preceding the survey, and on the risk factors predisposing children to diarrhoeal infections. Bivariate and multivariate logistic regression analyses with a $95 \%$ confidence interval and $p<0.05$ was used to identify the risk factors associated with childhood diarrhoeal disease.

Results: We found a prevalence of diarrhoea of $29.1 \%$ [95\% Cl (23.7-35.0)] among children < 5 years in Pajule Subcounty during the 2 weeks preceding the survey. Use of unprotected water sources, age of child caretaker, child weaning time and family size had significant associations with diarrhoeal morbidity.

Conclusion: The prevalence of childhood diarrhoea among children $<5$ years of age in rural settings of Pajule Subcounty was higher than the Ugandan national average. Use of unprotected water sources, age of child caretaker, child weaning time and family size were identified as predictors of diarrhoeal occurrence. These findings underscore the need for improving access to clean water and providing community health education as the best methods for fighting childhood diarrhoea in the study area.
\end{abstract}

Keywords: Bivariate, Logistic regression, Multivariate, Risk factor, Pajule

\section{Background}

Diarrhoea, defined as having unusually loose or watery stool that occur more frequently than usual within $24 \mathrm{~h}$ [1], remain among the most common causes of mortality and morbidity in children, particularly in low and middle-income countries. Worldwide, diarrhoea accounts for an estimated 3.6\% of the global burden of disease, as expressed in disability-adjusted life years [2], and it is the leading killer, accounting for approximately $8 \%$

\footnotetext{
* Correspondence: robopiro@gu.ac.ug

${ }^{1}$ Department of Biology, Faculty of Science, Gulu University, Laroo Division, Gulu, Uganda

Full list of author information is available at the end of the article
}

of all deaths among children $<5$ years despite the availability of simple effective treatments [3]. Although the global mortality from diarrhoea has been declining over the past 25 years, the disease is still a major cause of mortality in children $<5$ years of age in developing countries, contributing up to $21 \%$ of deaths [4].

In Uganda, diarrhoea is among the top four causes of morbidity in infants and young children [5]. The Uganda Demographic and Health Survey of 2016 reported that the prevalence of diarrhoea among children $<5$ years in Uganda was 20\% [6]. In 2017, diarrhoeal disease deaths reached $6.41 \%$ of total deaths, making the country to be ranked 27th worldwide [7]. Presently, diarrhoea still 
remains among the top ten causes of morbidity in the country, with rotavirus being responsible for about $40 \%$ of all diarrhoeal cases [8].

Pader District in northern Uganda was affected by the civil war between the Lord's Resistance Army (LRA) and the Uganda People's Defense Forces (UPDF) that plagued the region between the1980's and 2008. This resulted in the creation of internally displaced persons' camps (IDPs), disrupting social services delivery $[9,10]$. Currently, the district lags behind the rest of the country in terms of the human development indices and is characterized by high levels of poverty [11]. Infant mortality rate [IMR] in the district is standing at a staggering $180+$ per 1000 live births, with acute diarrhoea accounting for $8 \%$ of such deaths [12]. Sanitation remains a challenge with only $30 \%$ of the households having unimproved toilet facilities, and about 600,000 households do not have any toilet facility at all [13]. Despite these statistics, accurate information on prevalence and factors associated with diarrhoea in the district remain virtually unknown. The current study determined the prevalence of diarrhoea and risk factors among children $<5$ years old with the view to provide information that could be useful in planning interventions to reduce the burden of the disease in the district.

\section{Methods}

\section{Study area}

The study was conducted in Pajule Subcounty $\left(2^{0} 56^{\prime}\right.$ $23^{\prime \prime} \mathrm{N}$ and $32^{\circ} 56^{\prime} 38^{\prime \prime}$ E) located in Aruu North constituency, Pader District in northern Uganda [Fig. 1]. Pajule Subcounty consists of six parishes and has a population of 22,713, with 4050 of these being children below 5 years [11]. Like in other parts of northern Uganda, poverty level is higher than the national average, due to a combination of factors like the prolonged civil war that affected the entire northern region, cattle rustling by the Karimojong, and marginalisation that dates back to the colonial era [9]. The majority of the households derive their livelihood from subsistence farming; only $27 \%$ depend on earned income [13]. Water coverage has reduced from $57 \%$ when the population was in camps to only $38 \%$ as the communities returned to their homes [14].

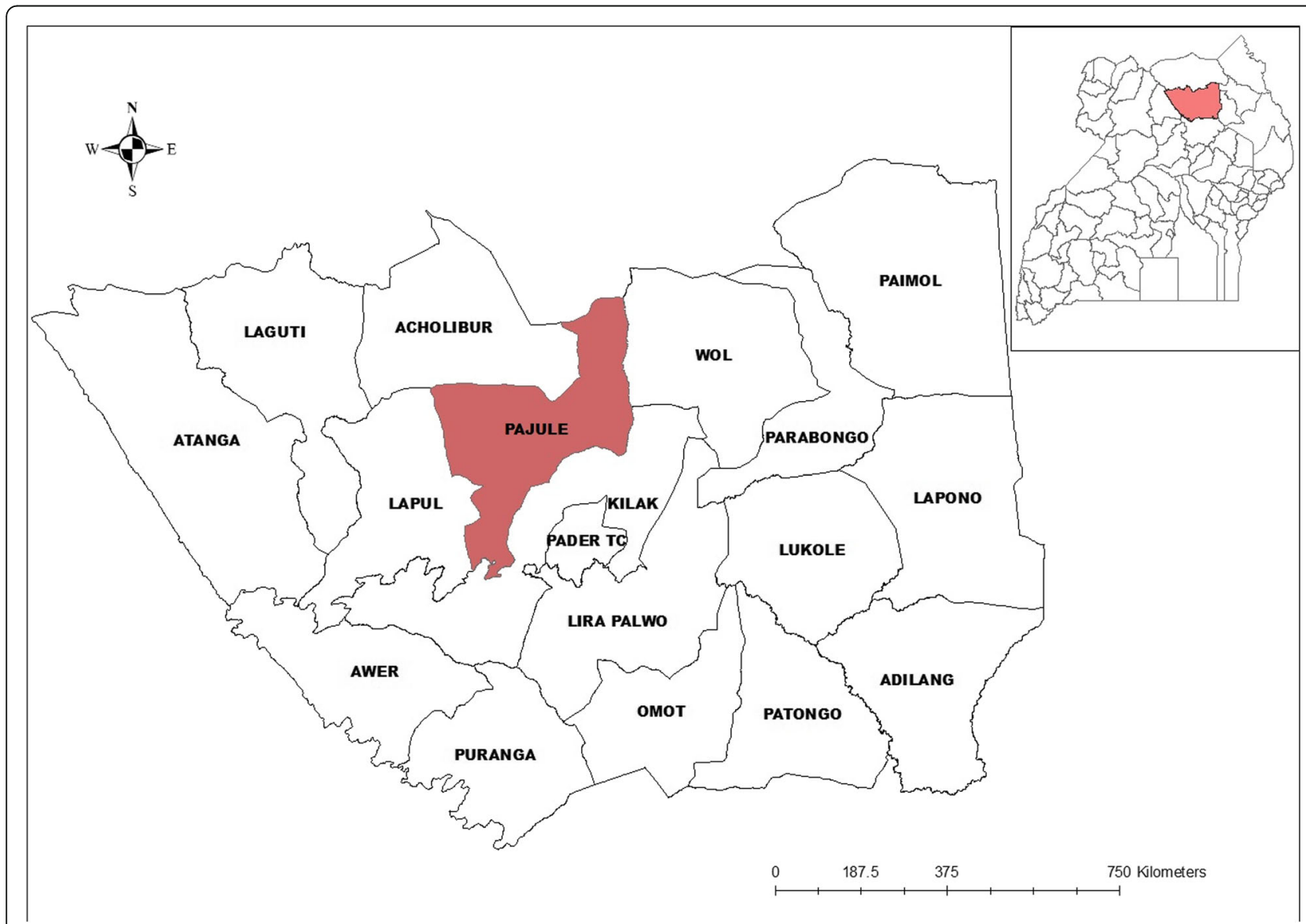

Fig. 1 Location of the study area (Pajule Sub-county) in Pader District, northern Uganda. Map was created by the authors using ArcGIS version 10.3.1 


\section{Study design and data collection}

A cross-sectional survey was conducted in April 2018 in four randomly selected parishes out of the six parishes in Pajule Subcounty. According to the 2014 National Housing and Population Census, Pajule Subcounty has approximately 4000 households, and so a sample size of 351 households was estimated using the Krejcie and Morgan table [15]. However, due to logistical constraints, non-response or unavailability of targeted respondents at the time of survey, we only sampled a total of 244 households. The number of households in each parish was determined using probability proportional to size, and from each parish, at least two villages were randomly selected using a random number. The list of households in each village was obtained from the respective Local Council chairpersons. Only individuals from households where the mother or caregiver was present and had a child $<5$ years old were interviewed. In cases, where there were more than one child $<5$ years in the same household, index child was selected by lottery method. Trained research assistants administered semistructured questionnaires based on the World Health Organization (WHO) guidelines [16]. The dependent or outcome variable was the presence of diarrhoea among children aged $<5$ years within the 14 days before the survey. This was evaluated by asking the mother or caregiver if the child involved in the study had suffered from diarrhoea within 14 days before the study. Independent variables included socio-demographic, socio-economic, environmental and behavioural factors. Socio-demographic and economic characteristics included age of the child, number of children under the age of five in the household, family size, age of the child's caregiver, sex of the child, the income status of the family, and the mother's or caregiver's education level. Environmental factors included type of water source, availability of animals in the homestead, presence of animals' houses, child's stool disposal practice, availability of latrines, ownership of latrine, hand washing practices, availability of kitchen, household's environmental cleanliness, and presence of utensils' drying racks. The behavioral characteristics included source of drinking water, boiling of water before consumption, frequency of warming cold food, weaning age, and age of food supplementation.

\section{Data analyses}

Descriptive analyses using frequency and percentages were used to summarize the independent and dependent variables. To obtain the associations between diarrhoea among children and risk factors, we used multivariable logistic regression. The adjusted odd ratios [AORs] of having diarrhoea with $95 \%$ confidence interval [CIs] and $P$ value $<0.05$ were used to describe associations. First, we conducted univariate analyses to determine the associations between diarrhoea and other associated factors using chi-square and binary logistic regression. Eight variables with $p$-values less than 0.05 in bivariate analyses were included in the final multivariable logistic regression. All analyses were done using IBM SPSS for windows version 25 .

\section{Results}

\section{General characteristics of study households}

Of the 244 households surveyed, $11.1 \%$ of the respondents were mothers or caretakers with no formal education while the majority (68\%) had primary level education (Table 1), and $20.9 \%$ had secondary education. In terms of latrine coverage, $79.9 \%$ of the households had latrines in their homesteads while $68.9 \%$ reported sharing of latrines with other nearby households. For those who had latrines, only $14.3 \%$ had hand-washing facilities erected near the latrines. The practice of disposal of children's stool was fairly well addressed with $80.7 \%$ of the respondents properly disposing of children's stool as opposed to $19.3 \%$ who disposed of tools unsafely. According to the World Health Organization [17], a child's stool is considered to be disposed of safely when he/she uses either the toilet or latrine and puts or buries the faeces in the toilet/latrine. Furthermore, majority (83.2\%) of the households gave food supplements to children when aged $>6$ months, and $49.2 \%$ weaned their children at the age of $>1$ year. Majority $(45.5 \%)$ of the respondents had a family size less than five individuals and only $63.5 \%$ of mothers/caretakers completed their immunization schedules as required (Table 1).

\section{Prevalence of diarrhoea and associated risk factors among children}

Overall, from a total of 224 households surveyed, 29.1\% [95\% CI (23.7-35.0)] reported episodes of diarrhoea in children $<5$ years in the two-week period prior to data collection. The diarrhoeal prevalence in males, 52\% [95\% CI (48.5-58.3)] and females, $48.0 \%$ [95\% CI (41.7-54.2)] did not differ significantly. Age group 13-24 months appeared most vulnerable, followed by $0-12$ months, and the lowest prevalence was in category $37-48$ months (Table 2). By age of caretaker, diarrhoea most commonly occurred among children whose mothers or caretakers were aged 16-30, 65.2\% [95\% CI (59.0-70.9)] and $\geq 31$ years, $32.4 \%$ [95\% CI (26.7-38.4)] than in those aged $\leq 15$ years, $2.5 \%$ [95\% CI (1.0-5.0)]. In the chi-square (Table 1) and univariable binary logistic regression analysis (Table 2 ), age of child caretaker, family size, nature of protection of drinking water source, availability of separate kitchen, child weaning time, warming of cold food, sharing of houses with domestic animals and mothers not washing hands at critical times had a $p$-value less than 0.05 and were further analyzed by multivariable logistic regression (Table 2). The multiple logistic regression revealed that the only factors significantly associated to diarrhoeal morbidity among children below 5 years in Pajule Subcounty 
Table 1 General characteristics of the households/respondents surveyed. Significant $p$ values in bold

\begin{tabular}{|c|c|c|c|c|c|c|}
\hline Variable & $n$ & Percentage & $95 \% \mathrm{Cl}$ & & $x^{2}$ & $p$ \\
\hline Sex of the child & & & Lower & Upper & & \\
\hline Male & 127 & 52.0 & 48.5 & 58.3 & 1.302 & 0.254 \\
\hline Female & 117 & 48.0 & 41.7 & 54.2 & & \\
\hline \multicolumn{7}{|l|}{ Age of child (months) } \\
\hline $0-12$ & 69 & 28.3 & 22.9 & 34.2 & 4.216 & 0.378 \\
\hline $13-24$ & 98 & 40.2 & 34.2 & 46.4 & & \\
\hline $25-36$ & 44 & 18.0 & 13.6 & 23.2 & & \\
\hline $37-48$ & 16 & 6.6 & 4.0 & 10.2 & & \\
\hline $49-59$ & 17 & 7.0 & 4.3 & 10.7 & & \\
\hline \multicolumn{7}{|c|}{ Number of under five children } \\
\hline Up to one & 115 & 47.1 & 40.9 & 53.4 & 0.997 & 0.318 \\
\hline Two or more & 129 & 52.9 & 46.6 & 59.1 & & \\
\hline \multicolumn{7}{|l|}{ Caretaker } \\
\hline Mother & 216 & 88.5 & 84.1 & 92.1 & 0.902 & 0.342 \\
\hline Others & 28 & 11.5 & 7.9 & 15.9 & & \\
\hline \multicolumn{7}{|c|}{ Age of mother/child caretaker } \\
\hline 6 to 15 & 6 & 2.5 & 1.0 & 5.0 & 6.729 & 0.035 \\
\hline 16 to 30 & 159 & 65.2 & 59.0 & 70.9 & & \\
\hline$\geq 31$ & 79 & 32.4 & 26.7 & 38.4 & & \\
\hline \multicolumn{7}{|c|}{$\begin{array}{l}\text { Education level of the mother } \\
\text { or child caretaker }\end{array}$} \\
\hline No formal education & 27 & 11.1 & 7.6 & 15.5 & 0.304 & 0.859 \\
\hline Primary & 166 & 68.0 & 62.0 & 73.6 & & \\
\hline Secondary and above & 51 & 20.9 & 16.2 & 26.3 & & \\
\hline \multicolumn{7}{|l|}{$\begin{array}{l}\text { Number of household } \\
\text { member/family size }\end{array}$} \\
\hline Less than 5 & 111 & 45.5 & 39.3 & 51.8 & 10.763 & 0.005 \\
\hline 6 to 9 & 94 & 38.5 & 32.6 & 44.7 & & \\
\hline 10 to 15 & 39 & 16.0 & 11.8 & 21.0 & & \\
\hline \multicolumn{7}{|l|}{ Income status of the family } \\
\hline Poor & 225 & 92.2 & 88.3 & 95.1 & 0.559 & 0.439 \\
\hline Rich & 19 & 7.8 & 4.9 & 11.7 & & \\
\hline \multicolumn{7}{|l|}{ Source of drinking water } \\
\hline Borehole & 20 & 8.2 & 5.2 & 12.1 & 4.724 & 0.094 \\
\hline Piped water & 56 & 23.0 & 18.0 & 28.5 & & \\
\hline Wells & 168 & 68.9 & 62.8 & 74.4 & & \\
\hline \multicolumn{7}{|l|}{ Nature of water source } \\
\hline Protected & 147 & 60.2 & 65.4 & 76.7 & 23.339 & $<0.001$ \\
\hline Unprotected & 97 & 39.8 & 23.3 & 34.6 & & \\
\hline \multicolumn{7}{|c|}{ Houses shared with domestic animals } \\
\hline No & 26 & 10.7 & 7.2 & 15.0 & 4.349 & 0.037 \\
\hline Yes & 218 & 89.3 & 85.0 & 92.8 & & \\
\hline \multicolumn{7}{|c|}{ Disposal of the youngest child's stool } \\
\hline Proper way & 197 & 80.7 & 75.4 & 85.3 & 1.411 & 0.235 \\
\hline Improper way & 47 & 19.3 & 14.7 & 24.6 & & \\
\hline
\end{tabular}


Table 1 General characteristics of the households/respondents surveyed. Significant $p$ values in bold (Continued)

\begin{tabular}{|c|c|c|c|c|c|c|}
\hline Variable & $n$ & Percentage & $95 \% \mathrm{Cl}$ & & $x^{2}$ & $p$ \\
\hline \multicolumn{7}{|l|}{ Latrine availability } \\
\hline Yes & 195 & 79.9 & 74.6 & 84.6 & 0.930 & 0.335 \\
\hline No & 49 & 20.1 & 15.4 & 25.4 & & \\
\hline \multicolumn{7}{|l|}{ Ownership of latrine } \\
\hline Shared & 76 & 31.1 & 25.6 & 84.6 & 0.771 & 0.380 \\
\hline Private & 168 & 68.9 & 62.8 & 74.4 & & \\
\hline \multicolumn{7}{|l|}{ Environmental cleanliness } \\
\hline Clean/safe & 174 & 71.3 & 65.4 & 76.7 & 0.672 & 0.412 \\
\hline Unclean/unhygienic & 70 & 28.7 & 23.3 & 34.6 & & \\
\hline \multicolumn{7}{|c|}{ Handwashing facilities near the latrine } \\
\hline Yes & 35 & 14.3 & 10.4 & 19.2 & 1.640 & 0.200 \\
\hline No & 209 & 85.7 & 80.8 & 89.6 & & \\
\hline \multicolumn{7}{|l|}{ Availability of separate kitchen } \\
\hline Yes & 192 & 78.7 & 73.2 & 83.5 & 7.335 & 0.007 \\
\hline No & 52 & 21.3 & 16.5 & 26.8 & & \\
\hline \multicolumn{7}{|l|}{ Racks for drying utensils } \\
\hline Yes & 58 & 23.8 & 18.8 & 29.4 & 0.386 & 0.534 \\
\hline No & 186 & 76.2 & 70.6 & 81.2 & & \\
\hline \multicolumn{7}{|l|}{ Warming of cold foods } \\
\hline Yes & 149 & 61.1 & 54.8 & 67.0 & 17.221 & $<0.001$ \\
\hline No & 95 & 38.9 & 33.0 & 45.2 & & \\
\hline \multicolumn{7}{|l|}{ Boiling of drinking water } \\
\hline Yes & 14 & 5.7 & 3.3 & 9.2 & 3.470 & 0.062 \\
\hline No & 230 & 94.3 & 90.8 & 96.7 & & \\
\hline \multicolumn{7}{|c|}{$\begin{array}{l}\text { Age of child started supplementary } \\
\text { food }\end{array}$} \\
\hline Less than 6 months & 26 & 10.7 & 7.2 & 15.0 & 5.575 & 0.062 \\
\hline $6-12$ months & 203 & 83.2 & 78.1 & 87.5 & & \\
\hline$>12$ months/not started & 15 & 6.1 & 3.6 & 9.7 & & \\
\hline \multicolumn{7}{|l|}{ Child weaning time } \\
\hline On breastfeeding & 109 & 47 & 38.5 & 50.9 & 7.420 & 0.024 \\
\hline Weaning $<1$ year & 15 & 6.1 & 3.6 & 9.7 & & \\
\hline Weaning $>1$ year & 120 & 49.2 & 42.9 & 55.4 & & \\
\hline \multicolumn{7}{|c|}{$\begin{array}{l}\text { Handwashing practices at critical } \\
\text { times }\end{array}$} \\
\hline Yes & 152 & 62.3 & 56.1 & 68.2 & 19.616 & $<0.001$ \\
\hline No & 92 & 37.7 & 31.8 & 43.9 & & \\
\hline \multicolumn{7}{|l|}{ Immunization status of child } \\
\hline Yes & 155 & 63.5 & 57.4 & 69.4 & 0.309 & 0.578 \\
\hline No & 89 & 36.5 & 30.6 & 42.6 & & \\
\hline
\end{tabular}

are age of mother/child caretaker, family size, child weaning time and use of unprotected water sources such as wells (Table 2). Children whose mothers/caretaker were aged $16-30$ years and $\geq 31$ years had 14 times [AOR: 14.275, 95\%CI (1.207-168.757)] and 12 times [AOR:
11.86, 95\%CI (1.066-131.928)] higher odds of diarrhoea than those whose caretaker were aged less than 15 years. Children whose households had 10-15 children had seven times higher odds of diarrhoea than children whose households had one child [AOR: 7.185, 95\%CI (1.353- 
Table 2 Multivariate logistic regression analyses of the risk factors associated with diarrhoea among children under five years in Pajule Subcounty, Pader District

\begin{tabular}{|c|c|c|c|c|c|c|c|}
\hline \multirow[t]{2}{*}{ Variables } & \multirow[b]{2}{*}{$n$} & \multicolumn{3}{|l|}{ Crude } & \multicolumn{3}{|l|}{ Adjusted odds ratio, AOR } \\
\hline & & Odds ratio, OR & $95 \% \mathrm{Cl}$ & $P$ value & Adjusted odds ratio, AOR & $95 \% \mathrm{Cl}$ & $P$ value \\
\hline
\end{tabular}

\begin{tabular}{lllll}
\hline Sex of the child & & & & \\
Male & 127 & 0.723 & $0.414-1.263$ & 0.255 \\
Female & 117 & 1 & &
\end{tabular}

Age of child (months)

$\begin{array}{lllll}0-12 & 69 & 1 & & \\ 13-24 & 98 & 0.804 & 0.412-1.568 & 0.522 \\ 25-36 & 44 & 0.973 & 0.424-2.233 & 0.949 \\ 37-48 & 16 & 2.857 & 0.594-13.736 & 0.190 \\ 49-59 & 17 & 1.905 & 0.493-7.355 & 0.350\end{array}$

Number of under five children

$\begin{array}{lllll}\text { Up to one } & 115 & 1 & 0.762-2.306 & 0.319 \\ \text { Two or more } & 129 & 1.325 & & \\ \text { Caretaker } & & & & \\ \text { Mother } & 216 & 1 & 0.611-4.075 & 0.346\end{array}$

Age of mother/child caretaker (years)

$\begin{array}{lllll}6 \text { to } 15 & 6 & 1 & & \\ 16 \text { to } 30 & 159 & 4.360 & 0.773-24.595 & 0.095 \\ \geq 31 & 79 & 7.294 & 1.230-43.261 & 0.029 \\ \text { Education level of the mother or child caretaker } & & \\ \text { No formal education } & 27 & 0.757 & 0.276-2.076 & 0.588 \\ \text { Primary } & 166 & 0.930 & 0.462-1.874 & 0.840 \\ \text { Secondary and above } & 51 & 1 & & \end{array}$

Number of household members/family size

$\begin{array}{lll}\text { Less than } 5 & 111 & 1 \\ 6 \text { to } 9 & 94 & 1.214\end{array}$

10 to 15

$0.676-2.181 \quad 0.516$

1

$1.880-3.895 \quad 0.003$

0.934

$0.431-2.024$

0.863

Income status of the family

$\begin{array}{lllll}\text { Poor } & 225 & 1.467 & 0.553-3.895 & 0.44 \\ \text { Rich } & 19 & 1 & & \end{array}$

Source of drinking water

$\begin{array}{lllll}\text { Borehole } & 20 & 1 & & \\ \text { Piped water } & 56 & 0.200 & 0.042-0.952 & 0.043 \\ \text { Wells } & 168 & 0.270 & 0.060-1.207 & 0.087\end{array}$

Nature of water source

$\begin{array}{lll}\text { Protected } & 147 & 1 \\ \text { Unprotected } & 97 & 0.248\end{array}$

Unprotected 97

Houses shared with domestic animals

$\begin{array}{lll}\text { No } & 26 & 1 \\ \text { Yes } & 218 & 0.288\end{array}$

$0.248 \quad 0.139-0.444<0.001$

7.185

1.353-38.147

0.021

Disposal of the youngest child's stool

Proper way

$197 \quad 1$ 
Table 2 Multivariate logistic regression analyses of the risk factors associated with diarrhoea among children under five years in Pajule Subcounty, Pader District (Continued)

\begin{tabular}{|c|c|c|c|c|c|c|c|}
\hline \multirow[t]{2}{*}{ Variables } & \multirow[b]{2}{*}{$\mathrm{n}$} & \multicolumn{3}{|l|}{ Crude } & \multicolumn{3}{|l|}{ Adjusted odds ratio, AOR } \\
\hline & & Odds ratio, OR & $95 \% \mathrm{Cl}$ & $P$ value & Adjusted odds ratio, AOR & $95 \% \mathrm{Cl}$ & $P$ value \\
\hline Improper way & 47 & 0.666 & $0.340-1.305$ & 0.237 & & & \\
\hline \multicolumn{8}{|l|}{ Latrine availability } \\
\hline Yes & 195 & 1 & & & & & \\
\hline No & 49 & 0.721 & $0.370-1.404$ & 0.336 & & & \\
\hline \multicolumn{8}{|l|}{ Ownership of latrine } \\
\hline Shared & 76 & 0.769 & $0.428-1.383$ & 0.380 & & & \\
\hline Privately & 168 & 1 & & & & & \\
\hline \multicolumn{8}{|c|}{ Environmental cleanliness } \\
\hline Clean/safe & 174 & 1 & & & & & \\
\hline Unclean/unhygienic & 70 & 0.778 & $0.427-1.418$ & 0.413 & & & \\
\hline \multicolumn{8}{|c|}{ Handwashing facilities near the latrine } \\
\hline Yes & 35 & 1 & & & & & \\
\hline No & 209 & 0.566 & $0.235-1.364$ & 0.205 & & & \\
\hline \multicolumn{8}{|c|}{ Availability of separate kitchen } \\
\hline Yes & 192 & 1 & & & & & \\
\hline No & 52 & 0.420 & $0.222-0.795$ & 0.008 & & & NS \\
\hline \multicolumn{8}{|l|}{ Racks for drying utensils } \\
\hline Yes & 58 & & & & & & \\
\hline No & 186 & 0.810 & $0.416-1.576$ & 0.535 & & & \\
\hline \multicolumn{8}{|l|}{ Warming of cold foods } \\
\hline Yes & 149 & 0.305 & $0.172-0.541$ & $<0.001$ & & & NS \\
\hline No & 95 & & & & & & \\
\hline \multicolumn{8}{|l|}{ Boiling of drinking water } \\
\hline Yes & 14 & 1 & & & & & \\
\hline No & 230 & 0.176 & $0.023-1.370$ & 0.097 & & & \\
\hline \multicolumn{8}{|c|}{ Age of child started supplementary food } \\
\hline Less than 6 months & 26 & 1 & & & & & \\
\hline $6-12$ months & 203 & 2.195 & $0.958-5.033$ & 0.063 & & & \\
\hline$>12$ months & 15 & 5.571 & $1.042-29.780$ & 0.045 & & & \\
\hline \multicolumn{8}{|l|}{ Child weaning time } \\
\hline On breastfeeding & 109 & 1 & & & 1 & & \\
\hline Weaning $<1$ year & 15 & 0.242 & $0.079-0.738$ & 0.879 & 0.142 & $0.034-0.595$ & 0.008 \\
\hline Weaning $>1$ year & 120 & 0.956 & $0.533-1.714$ & 0.015 & 1.140 & $0.549-2.366$ & 0.726 \\
\hline \multicolumn{8}{|c|}{ Mothers' handwashing practices at critical times } \\
\hline Yes & 152 & 1 & & & & & \\
\hline No & 92 & 0.281 & $0.158-0.499$ & $<0.001$ & & & NS \\
\hline \multicolumn{8}{|c|}{ Immunization status of child } \\
\hline Yes & 155 & 1 & & & & & \\
\hline No & 89 & 0.579 & $0.660-2.105$ & 0.579 & & & \\
\hline
\end{tabular}

NS not significant

$O R$ odd ratio

$A O R$ adjusted odd ratio

$\mathrm{Cl}$ confidence interval

Significant results are bold 
38.147)]. The risk of developing diarrhoea in children whose households use protected water source had a $68 \%$ lower chance [AOR: 0.322, 95\%CI (0.156-0.665)] compared to children in households who use unprotected water source (Table 2). Finally, children exclusively breastfed had 85\% lower chance [AOR: 0.1542, 95\%CI (0.034$0.595)$ ] of diarrhoea than children who were weaned early (<1 year).

\section{Discussion}

We assessed the prevalence and risk factors of diarrhoea among children under 5 years old in Pajule Subcounty in Pader District, northern Uganda. Overall, the mothers or caretakers reported a prevalence of diarrhoea of $29.1 \%$, which is lower than the $40.8 \%$ reported in neighboring Agago District [18], and elsewhere in Uganda; 41.3\% in Adjumani Refugee Camp in West Nile [19] and 40.3\% in Sembabule District [20]. However, the reported prevalence is higher than the $20 \%$ reported for the same age group in the Uganda Demographic and Health Survey of 2016 [6]. The high prevalence of diarrhoea in Pajule Subcounty than the national average could be due to the fact that the area suffered a prolonged conflict which disrupted social services like education and health, infrastructural development, and the overall economic fabric of the society [9]. For example, $11.1 \%$ of the mothers or caretakers had no formal education, and the majority $(68.0 \%)$ had stopped in the lower primary (Primary one to four). Although this was not significant in our analyses, the role of formal education cannot be under-rated, as less educated people are less likely to take their hygiene and sanitation seriously, as well as those of their children.

Our results showed that family size, the age of child caretaker, child-weaning time, nature of protection of water source had significant associations with diarrhoeal morbidity. Children whose households had 10-15 children had seven times higher odds of diarrhoea than children whose households had one child. High number of individuals in a household potentially compromises hygiene and sanitation, making children more prone to contact with diarrhoeal pathogens. In Pajule, house sizes are mostly small temporary huts where humans, and sometimes pets, occupy the limited space, further reducing cleanliness in the household.

The present study also showed that exclusively breastfed children had $85 \%$ lower chance of diarrhoea than children who were weaned early (at less than 1 year). Given the poor hand washing practices and general unhygienic conditions observed in this study, preparations of weaning foods have the potential of spreading diarrhoeal causing germs to the infants. Weaning foods prepared under unhygienic conditions are frequently heavily contaminated with pathogens and are thus a major factor in the cause of diarrhoeal diseases and associated malnutrition [21]. Our results are consistent with many previous studies that have indicated that the addition of early food supplements to infants fed under prevailing environmental conditions in developing countries lead to their increased diarrhoeal attacks and associated reduced food intake [22].

Children whose caretakers were older had 12-14 times higher odds of diarrhoea than caretakers aged less than 15 years. This finding is surprising because previous studies have shown that young mothers are associated with a higher odds of diarrhoea than older mothers [23]. This is because, older caretakers tend to have experience in taking care of children compared to their younger counterparts and hence reducing childhood diarrhoeal incidences. Our results could however be explained by the fact that the majority of mothers were in teenage age (age 16-30) (Table 1).

Our study also showed that the risk of developing diarrhoea in children whose households use protected water sources was $68 \%$ lower compared to their counterparts who use unprotected water sources. This finding is similar with a study by [24] in Kenya who found that sources of drinking water was one of the household characteristics that had significant influence on childhood diarrhoea. However, a study conducted in southwest Ethiopia by [25] did not find any significant association of diarrhoeal occurrence and drinking water sources. Nevertheless, unprotected water sources have higher chances of fetching germs from the intruding animals or from running water carrying waste matters. In Pajule, like the rest of northern Uganda, access to safe water is a major challenge due to inadequate funding for construction of clean water sources and/or inadequate training of users in water source maintenance [26]. Due to lack of access to safe water, communities are forced to utilize unsafe sources such as streams, which requires boiling to make it safe.

\section{Conclusions}

In the current study, prevalence of diarrhoea among under-five children in the rural setting of Pajule Subcounty in Pader was found to be high (29.1\%). The use of unprotected water sources, age of child caretaker, child weaning time and family size had significant associations with diarrhoeal occurrence. These are mainly household level factors that can be mitigated by provision of access to clean water and community health education to fight childhood diarrhoea in the study area.

\section{Study limitations}

Our study is prone to recall bias since it was based on respondents' recalling of diarrhoeal history in their children within the last 2 weeks preceding the survey. 
However, we asked the mothers to report on the diarrhoea episode within 2 weeks from the time of the interview to reduce on recall bias. Additionally, diarrhoea prevalence was based on self-reported screening and was not further confirmed. Also, being cross-sectional in design did not take into account seasonal variation in the prevalence; data was collected in April 2018, which is the beginning of the wet season in northern Uganda. Follow up studies should cater for seasonal variation as well as stool and water analysis for the diarrhoeal causal agents and contaminations.

\section{Abbreviations \\ AOR: Adjusted Odds Ratio; Cl: Confidence Interval; IDPs: Internally Displaced Persons; IMR: Infant Mortality Rate; LRA: Lord's Resistance Army; \\ SPSS: Statistical Package for the Social Sciences; UPDF: Uganda People's \\ Defense Forces; WHO: World Health Organization}

\section{Acknowledgements}

We appreciate the support of the In-charge of Pajule Health Centre IV, the Local Council I Chairpersons of the sampled villages, and the communities of Pajule Subcounty for providing responses during this study.

\section{Authors' contributions}

$\mathrm{SO}$ and $\mathrm{RO} 2$ conceived and designed the study, collected data, performed initial analyses and wrote initial draft of manuscript. GM, RO1 and GO critically revised the manuscript. All authors read and approved the final version of the manuscript.

\section{Funding}

The research work did not receive any specific grant from funding agencies in the public, commercial or not-for-profit sectors.

\section{Availability of data and materials}

The datasets used and/or analysed during the current study are available from the corresponding author on reasonable request.

\section{Ethics approval and consent to participate}

Ethical clearance was obtained from the Gulu University Research Ethics Committee [GUREC-077-18]. Households' heads were briefed verbally about the study and required to sign consent forms translated into the local language. For participants under 16 years old, written informed consent was obtained from their parents or guardians. The Local Council I Chairpersons of the different villages were also made aware of the exercise in their villages. The confidentiality of information was kept during and after the interview by using codes rather than participants' names.

\section{Consent for publication}

Not applicable.

\section{Competing interests}

The authors declare that they have no competing interests.

\begin{abstract}
Author details
'Department of Biology, Faculty of Science, Gulu University, Laroo Division, Gulu, Uganda. ${ }^{2}$ Department of Environmental and Biological Sciences, Faculty of Science and Forestry, University of Eastern Finland, Joensuu, Finland. ${ }^{3}$ Department of Biology, Faculty of Science, Muni University, Arua, Uganda. ${ }^{4}$ Department of Biosystems Engineering, Faculty of Agriculture and Environment, Gulu University, Laroo Division, Gulu, Uganda.
\end{abstract}

Received: 23 September 2019 Accepted: 7 January 2020 Published online: 13 January 2020

\section{References}

1. ANSD II. Sénégal: Enquête Démographique et de Santé" "Continue (EDSContinue 2014). Rockville: Agence Natl la Stat la Démographie ICF Int 2015 (in French); 2015.
2. Murray CJL, Vos T, Lozano R, Naghavi M, Flaxman AD, Michaud C, et al. Disability-adjusted life years (DALYs) for 291 diseases and injuries in 21 regions, 1990-2010: a systematic analysis for the global burden of disease study 2010. Lancet. 2010;380:2197-223.

3. WHO. WHO Fact Sheet. 2017. Available: https://www.who.int/news-room/ fact-sheets/detail/diarrhoeal-disease

4. Liu L, Oza S, Hogan D, Perin J, Rudan I, Lawn JE, et al. Global, regional, and national causes of child mortality in 2000-13, with projections to inform post2015 priorities: an updated systematic analysis. Lancet. 2015;385:430-40.

5. Ministry of Health. Statistical Abstract. Kampala, Uganda. 2010. Retrieved from http://www.health.go.ug/hmis/public/files/moh_statistical_abstract_2 010.pdf. Accessed 23 Dec 2019.

6. Uganda Bureau of Statistics Kampala. Uganda Demographic and Health Survey 2016 Key Indicators Report Uganda. p.169. https://dhsprogram.com/ pubs/pdf/FR333/FR333.pdf

7. WHO. Preventing Diarrhoea through better water, sanitation and hygiene: Exposures and impacts in low- and middle-income countries. 2014.

8. Bwogi J, Malamba S, Kigozi B, Namuwulya P, Tushabe P, Kiguli S, et al. The epidemiology of rotavirus disease in under-five-year-old children hospitalized with acute diarrhea in central Uganda, 2012-2013. Arch Virol. 2016;161:999-1003.

9. PRDP. Peace, Recovery and Development Plan for Northern Uganda (PDRP)2007-2010. 2007.

10. Royo JM. War and peace scenarios in northern Uganda; 2008.

11. Uganda Bureau of Statistics. The National Population and Housing Census 2014 - Main Report, Kampala, Uganda. 2016. Retrieved from https://unstats. un.org/unsd/demographic/sources/census/wphc/Uganda/UGA-2016-05-23. pdf. Accessed 19 Sept 2019.

12. Ministry of Health. Uganda Annual Health Sector Performance Report. 2017.

13. Uganda Bureau of Statistics. The National Population and Housing Census 2014 -Area Specific Profile Series, Kampala, Uganda. 2017. Retrieved from https:/www.ubos.org/wp-content/uploads/publications/2014CensusProfiles/ PADER.pdf. Accessed 19 Sept 2019.

14. Pader District Local Government. Higher local government statistical abstract Pader District. 2016.

15. Krejcie RV, Morgan DW. Determining sample size for research activities. Educ Psychol Meas. 1970;30:607-10.

16. WHO/UNICEF. Core Questions on Drinking Water and Sanitation for Household Surveys. Geneva: WHO Press; 2006.

17. WHO, UNICEF. Core Questions on Drinking-Water and Sanitation for Household Surveys. Geneva: World Health Organisation and UNICEF; 2006.

18. Ocamanono GB. Prevalence of diarrhoea and its associated factors among children under five years in Agago District, Uganda; 2018.

19. Ayiga I, Nick G. Pevalence and factors associated with diarrhoea among children under five years in Nyumanzi Refugee Settlement Camp Adjumani District, Uganda. Kampala: Master thesis: Makerere University; 2015. Available: http://hdl.handle.net/10570/5705

20. Mbonye AK. Risk factors for diarrhoea and upper respiratory infections among children in a rural area of Uganda. J Heal Popul Nutr. 2004;22:52-8.

21. Motarjemi Y, Käferstein F, Moy G, Quevedo F. Contaminated weaning food: a major risk factor for diarrhoea and associated malnutrition. Bull World Health Organ. 1993;71:79.

22. Huffman SL, Combest C. Role of breast-feeding in the prevention and treatment of diarrhoea. J Diarrhoeal Dis Res. 1990;8:68-81.

23. Ghasemi AA, Talebian A, Masoudi Alavi NMG. Knowledge of mothers in Management of Diarrhea in under-five children, inKashan, Iran. Nurse Midwifery. 2013;2:158-62. https://doi.org/10.5812/nms.10393.

24. Mbugua S, Musikoyo E, Ndungi F, Sang R, Kamau-Mbuthia E, Ngotho D. Determinants of diarrhea among young children under the age of five in Kenya, evidence from KDHS 2008-09. African Popul Stud. 2014;28:1046.

25. Gebru T, Taha M, Kassahun W. Risk factors of diarrhoeal disease in underfive children among health extension model and non-model families in Sheko district rural community, Southwest Ethiopia: comparative crosssectional study. BMC Public Health. 2014;14:395. https://doi.org/10.1186/ 1471-2458-14-395.

26. Martin E, Petty C, Acidri J. Livelihoods in crisis: a longitudinal study in Pader, Uganda. London: HPG, ODI; 2009 .

\section{Publisher's Note}

Springer Nature remains neutral with regard to jurisdictional claims in published maps and institutional affiliations. 